\title{
Investigations related to scientific deep drilling to study reservoir-triggered earthquakes at Koyna, India
}

\author{
Harsh Gupta • N. Purnachandra Rao $\cdot$ Sukanta Roy $\cdot$ Kusumita Arora $\cdot$ V. M. Tiwari · Prasanta K. Patro • \\ H. V. S. Satyanarayana $\cdot$ D. Shashidhar $\cdot$ K. Mallika $\cdot$ Vyasulu V. Akkiraju $\cdot$ Deepjyoti Goswami $\cdot$ Digant Vyas \\ G. Ravi • K. N. S. S. S. Srinivas · M. Srihari • S. Mishra • C. P. Dubey • D. Ch. V. Raju • Ujjal Borah \\ K. Chinna Reddy • Narendra Babu • Sunil Rohilla · Upasana Dhar • Mrinal Sen • Y. J. Bhaskar Rao • \\ B. K. Bansal · Shailesh Nayak
}

Received: 17 April 2014 / Accepted: 11 December 2014 / Published online: 23 December 2014

(C) Springer-Verlag Berlin Heidelberg 2014

\begin{abstract}
Artificial water reservoir-triggered earthquakes have continued at Koyna in the Deccan Traps province, India, since the impoundment of the Shivaji Sagar reservoir in 1962. Existing models, to comprehend the genesis of triggered earthquakes, suffer from lack of observations in the near field. To investigate further, scientific deep drilling and setting up a fault zone observatory at depth of 5-7 km is planned in the Koyna area. Prior to undertaking deep drilling, an exploratory phase of investigations has been launched to constrain subsurface geology, structure and heat flow regime in the area that provide critical inputs for the design of the deep borehole observatory. Two core boreholes drilled to depths of 1,522 and 1,196 m have penetrated the Deccan Traps and sampled the granitic basement in the region for the first time. Studies on cores provide new and direct information regarding the thickness of the Deccan Traps, the absence of infra-Trappean sediments and the nature of the underlying basement rocks. Temperatures estimated at a depth of $6 \mathrm{~km}$ in the area, made on the basis of heat flow and thermal properties data sets, do not exceed $150{ }^{\circ} \mathrm{C}$. Low-elevation airborne gravity gradient and magnetic data sets covering 5,012 line $\mathrm{km}$, together with
\end{abstract}

H. Gupta $(\bowtie)$

National Disaster Management Authority, New Delhi, India

e-mail: harshg123@gmail.com

N. Purnachandra Rao $\cdot$ S. Roy $\cdot$ K. Arora $\cdot$ V. M. Tiwari ·

P. K. Patro $\cdot$ H. V. S. Satyanarayana $\cdot$ D. Shashidhar

K. Mallika $\cdot$ V. V. Akkiraju $\cdot$ D. Goswami $\cdot$ D. Vyas $\cdot$ G. Ravi

K. N. S. S. S. Srinivas - M. Srihari - S. Mishra - C. P. Dubey ·

D. C. V. Raju · U. Borah · K. Chinna Reddy · N. Babu •

S. Rohilla · U. Dhar · M. Sen · Y. J. Bhaskar Rao

CSIR-National Geophysical Research Institute, Hyderabad, India

B. K. Bansal · S. Nayak

Ministry of Earth Sciences, New Delhi, India high-quality magnetotelluric data at 100 stations, provide both regional information about the thickness of the Deccan Traps and the occurrence of localized density heterogeneities and anomalous conductive zones in the vicinity of the hypocentral zone. Acquisition of airborne LiDAR data to obtain a high-resolution topographic model of the region has been completed over an area of $1,064 \mathrm{~km}^{2}$ centred on the Koyna seismic zone. Seismometers have been deployed in the granitic basement inside two boreholes and are planned in another set of six boreholes to obtain accurate hypocentral locations and constrain the disposition of fault zones.

Keywords Koyna $\cdot$ Triggered seismicity $\cdot$ Scientific drilling $\cdot$ Earthquake $\cdot$ Reservoir

\section{Introduction}

Earthquakes triggered by filling of artificial water reservoirs have been reported at about 100 sites worldwide during the past seven decades (Gupta 2002, 2011). Damagingtriggered earthquakes exceeding magnitude six occurred at Hsingfengkiang (1962), Kariba (1963), Kremasta (1966) and Koyna (1967). The occurrence of reservoir-triggered seismicity (RTS) has been associated with a number of potential factors including the rate of loading, highest water level reached and the duration of retention of high water levels (Kaiser 1953; Gupta et al. 1972a, b). Other studies have investigated the role of reservoir loading (e.g., Gough and Gough 1970a, b; Bell and Nur 1978; Roeloffs 1988) and the influence of pore fluid pressure (Snow 1972; Talwani et al. 1999; Do Nascimento et al. 2004). While major advancements have been made towards elucidating the role of individual parameters in triggering earthquakes, an integrated model that explains the genesis of RTS is unavailable. 
Fig. 1 Seismic stations and earthquakes in Koyna-Warna region. KRFZ Koyna River fault zone, $D$ Donechiwada fault, $P 1$ fault parallel to Patan fault, $L 1$, L2, L3 and L4 NW-SE trending fractures (fault geometry by Talwani 1997b). Inset Koyna on India's map

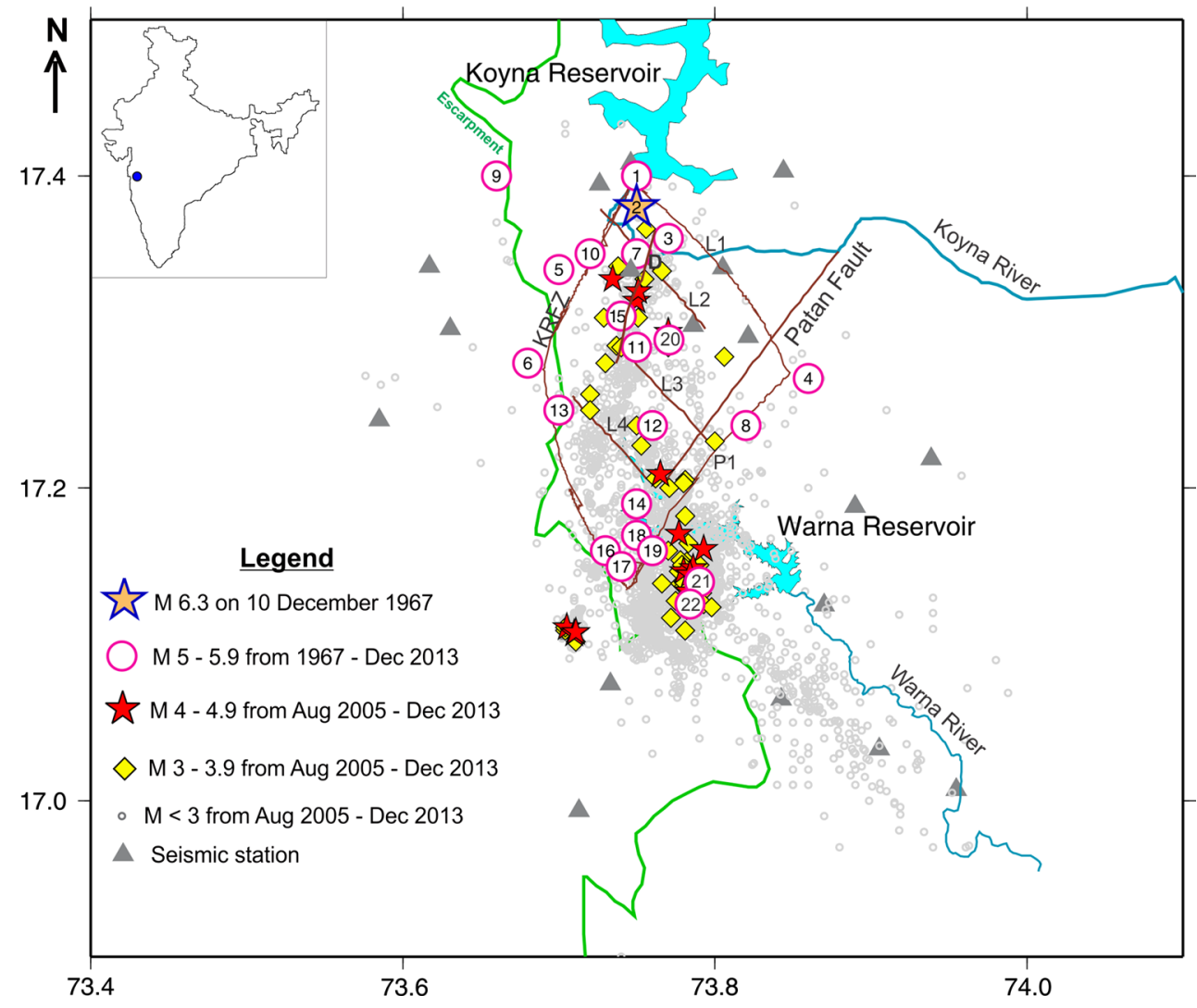

The Koyna region, located in the $\sim 65 \mathrm{Ma}$ old Deccan Traps of western India (Fig. 1), is a classical site of RTS. Triggered earthquakes started occurring soon after the impoundment of the Shivaji Sagar Lake formed by the Koyna Dam in 1962 and have continued till now. This includes the largest triggered earthquake of $M 6.3$ on 10 December 1967, $22 M \geq 5$ earthquakes, more than $200 M \geq 3.5$ earthquakes and several hundred smaller earthquakes (Fig. 1). There was an impetus in triggered earthquakes following the impoundment of the nearby Warna reservoir in 1985. A strong association of the earthquake activity is observed with the annual loading and unloading cycles of the Koyna and nearby Warna reservoirs (Fig. 2). The entire seismic activity is restricted to $\sim 30 \mathrm{~km} \times 20 \mathrm{~km}$ area, and there is no other earthquake source within $\sim 50 \mathrm{~km}$ of the Koyna Dam. The depth of these earthquakes is limited to about $10 \mathrm{~km}$, with almost $80 \%$ occurring between 1 and $6 \mathrm{~km}$ depths (Gupta and Rastogi 1976; Gupta 1992, 2002; Talwani 1997a).

Since 2005, a network of ten digital seismograph stations has been operated by the Council for Scientific and Industrial Research (CSIR)-National Geophysical Research Institute (NGRI), Hyderabad, in the KoynaWarna region and earthquake parameters are estimated in near real time. Earthquakes of $M \sim 4$ are found to be
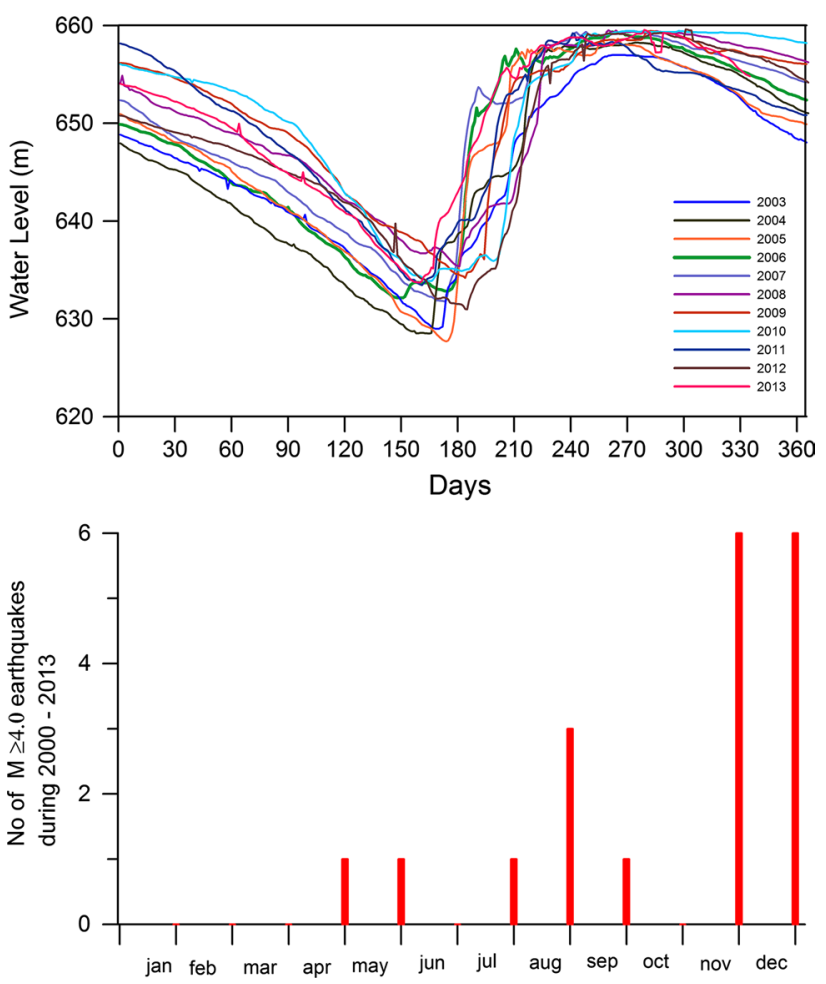

Fig. 2 Annual variation of Koyna reservoir water levels during 2003-2013 and monthly number of $M \geq 4.0$ earthquakes 
preceded by well-defined nucleation, and real-time identification of nucleation has led to short-term forecasts (Gupta et al. 2006, 2007, 2011a). Over the years, a considerable shift in the seismic activity to the south has been observed. From moment tensor inversion studies, it can be seen that focal mechanisms are governed by pure normal type in the Warna region, whereas a significant component of strikeslip dominates in the Koyna region. Good estimates of focal depths are obtained by waveform modelling (Shashidhar et al. 2011, 2013).

Although several studies have clearly established the association of continued triggered earthquakes at Koyna with the loading and unloading of the Koyna and Warna reservoirs, the triggering mechanism is little understood. The existing models to comprehend the genesis of RTS suffer from lack of observations in the near field of the earthquakes. A proposal for scientific deep drilling and setting up a deep borehole observatory to study critical parameters in the near field of earthquakes was discussed and agreed upon at the 2011 ICDP International Workshop held at Hyderabad and Koyna (Gupta et al. 2011b).

Prior to undertaking deep drilling, an exploratory phase of investigations aimed at providing critical inputs to the location and design of the deep borehole observatory was launched by the Ministry of Earth Sciences, Government of India in collaboration with the CSIR-NGRI, India. Studies during this phase include (1) exploratory drilling and geophysical logging to constrain subsurface geology and rock properties, (2) heat flow measurements and modelling of subsurface temperatures, (3) airborne gravity gradiometry and magnetics to obtain 3D subsurface structure in and around the Koyna seismic zone, (4) magnetotellurics to map the local and regional subsurface electrical conductivity structure and thickness of Deccan Traps, (5) airborne LiDAR to obtain a high-resolution topographic model of the forest-covered seismic zone and (6) borehole seismology to better constrain hypocentre locations and delineation of fault zones. The deployment plan for the exploratory phase investigations is shown in Fig. 3.

In this paper, we report (1) the first results obtained from the exploratory phase of investigations carried out during the past 3 years and (2) discuss the probable location, design and instrumentation plan of the proposed Koyna deep borehole in the light of the results obtained so far.

\section{Exploratory phase investigations}

\section{Drilling and logging}

Prior to undertaking the deep drilling, an exploratory phase of drilling of ten boreholes and related investigations is ongoing with the intent of constraining the subsurface

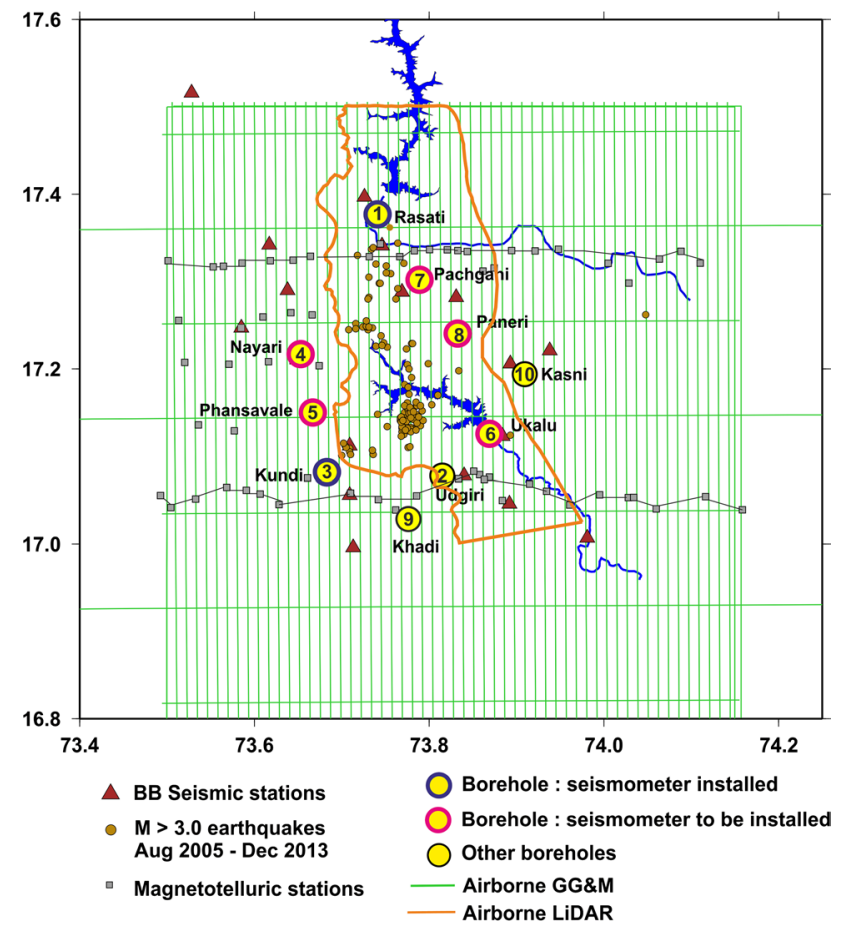

Fig. 3 The study area indicating the installation or deployment plan of the various experiments undertaken in the preparatory phase of the deep drilling programme. Earthquakes of $M \geq 3.0$ occurred during August 2005 to December 2013. MT-1 and MT-2 indicate the magnetotelluric profiles passing through Rasati in the north and Udgiri in the south, respectively

geology, physical and mechanical properties of rocks, temperature and stress regimes. These data constitute critical inputs for designing the proposed deep borehole observatory at a depth of 5-7 km. The thickness of Deccan Traps and the nature of underlying rocks were uncertain as previous drilling in this region was limited to shallow exploration boreholes within the Deccan Traps. In the present study, each borehole is planned to go through the Deccan basalt pile and a few $100 \mathrm{~m}$ into the underlying basement rocks. The first two cored boreholes, Rasati (KBH-1) near Koyna and Udgiri (KBH-2) to the south of Warna, have been completed to depths of 1,522 and $1,196 \mathrm{~m}$, respectively. The two boreholes broadly mark the northern and southern limits of the Koyna seismic zone (Fig. 3). Studies on cores and downhole measurements have brought out new and direct information about the thickness and properties of the Deccan Traps in the area and the nature of the underlying basement rocks, which had remained elusive so far (Rao et al. 2013; Roy et al. 2013a, b). Scientific investigations in the boreholes are expected to provide precise information about structure and physical properties of the subsurface rock volume in the vicinity of the Koyna seismic zone.

So far, drilling has provided answers to two important questions. The thickness of Deccan Traps in the 


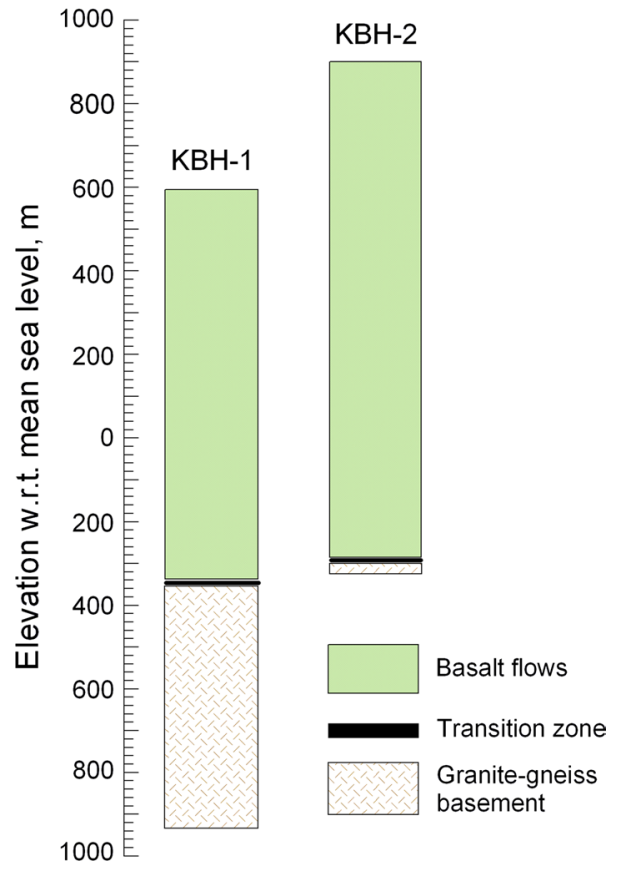

Fig. 4 General lithologic sections in boreholes Rasati (KBH-1) and Udgiri (KBH-2), showing the thicknesses of basalt pile and transition zone overlying a granite-gneiss basement. The collar elevations of $\mathrm{KBH}-1$ and $\mathrm{KBH}-2$ are 580 and 900 m, respectively

Koyna-Warna area ranges between 933 and 1,185 m, and there are no sediments between the thick lava pile and the underlying granitic basement (Fig. 4). Significantly, the thickness of the Deccan Traps is consistent with the inference from recent broadband seismic monitoring in the area that shows a conspicuous absence of earthquakes in the top $\sim 1 \mathrm{~km}$ (Gupta et al. 2011a). Cores recovered from the borehole have revealed a flood basalt pile comprising up to 25 lava flows of variable thicknesses, with each flow characterized by a vesicular and/or amygdaloidal layer underlain by fine grained massive basalt. Often, the upper parts of the flows are brecciated. Red bole beds up to several tens of centimetres in thickness, representing weathered basalt during the hiatus between two successive lava flows, have been observed at multiple depths at both sites. A typical lava flow is shown in Fig. 5. The basement rock is dominantly granite-gneiss, with a relatively short (a few metres thick) transition zone between basalt and the basement. This zone marks the interaction of hot lava with the weathered granitoid surface prior to the Deccan volcanism. Moderate to heavily fractured zones, ranging in thickness between a few centimetres to a few metres, have been observed in the basement granite-gneiss. Occasionally, well-developed slickenlines on the fractured surfaces have been noted within the basement rock.

Detailed geophysical logging studies are being carried out including gamma, SP, SPR, calliper, temperature and

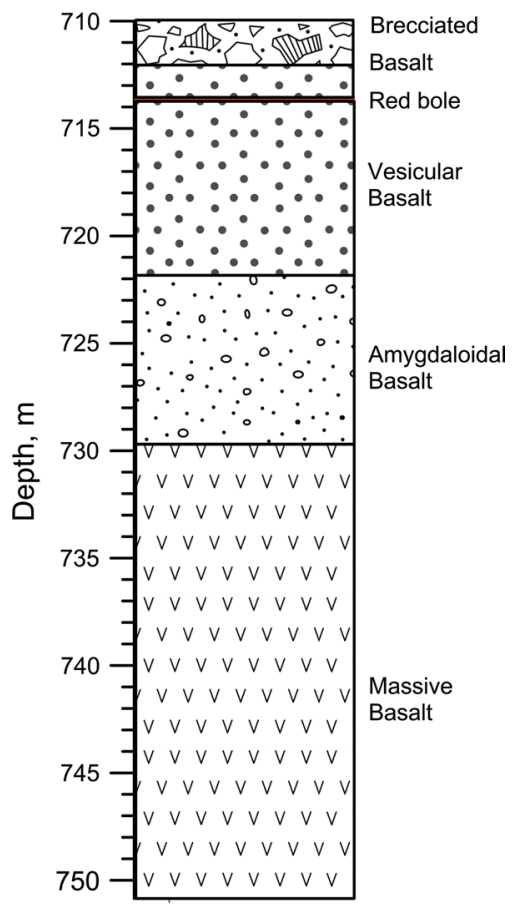

Fig. 5 A typical lava flow comprising a brecciated top, vesicular/ amygdaloidal middle part and massive basalt base in borehole $\mathrm{KBH}-1$

sonic logging. A sample litholog between 800 and $950 \mathrm{~m}$ in the borehole KBH-1 at Rasati near Koyna correlated with the various logs is shown in Fig. 6. It can be seen that the transition between basalt and granitic basement at a depth of $933 \mathrm{~m}$ is clearly brought out by most of the logs.

\section{Heat flow studies}

Heat flow, together with data on thermal properties of rocks, provides constraints for modelling the subsurface temperature regime in the Earth's crust. Because scientific deep drilling to a depth of 5-7 $\mathrm{km}$ is proposed in the Koyna-Warna area, knowledge of temperature in the upper parts of the crust is critical for deploying appropriate drilling technology and for designing the deep borehole observatory.

Heat flow of $41 \mathrm{~mW} \mathrm{~m}^{-2}$ in the Koyna region was previously reported from measurements in two boreholes located in Koyna-Alore (Gupta and Gaur 1984). Each borehole, 200 m deep, was drilled through lava flows comprising massive as well as vesicular basalt. Subsurface temperature models based on such data were poorly constrained due to lack of reliable heat flow determination from deep boreholes and thermal properties and radiogenic heat production measurements from the underlying basement rocks.

In the present study, equilibrium temperature measurements were taken up to a depth of $1,522 \mathrm{~m}$ in the borehole KBH-1 near Koyna, which penetrated the entire Deccan 


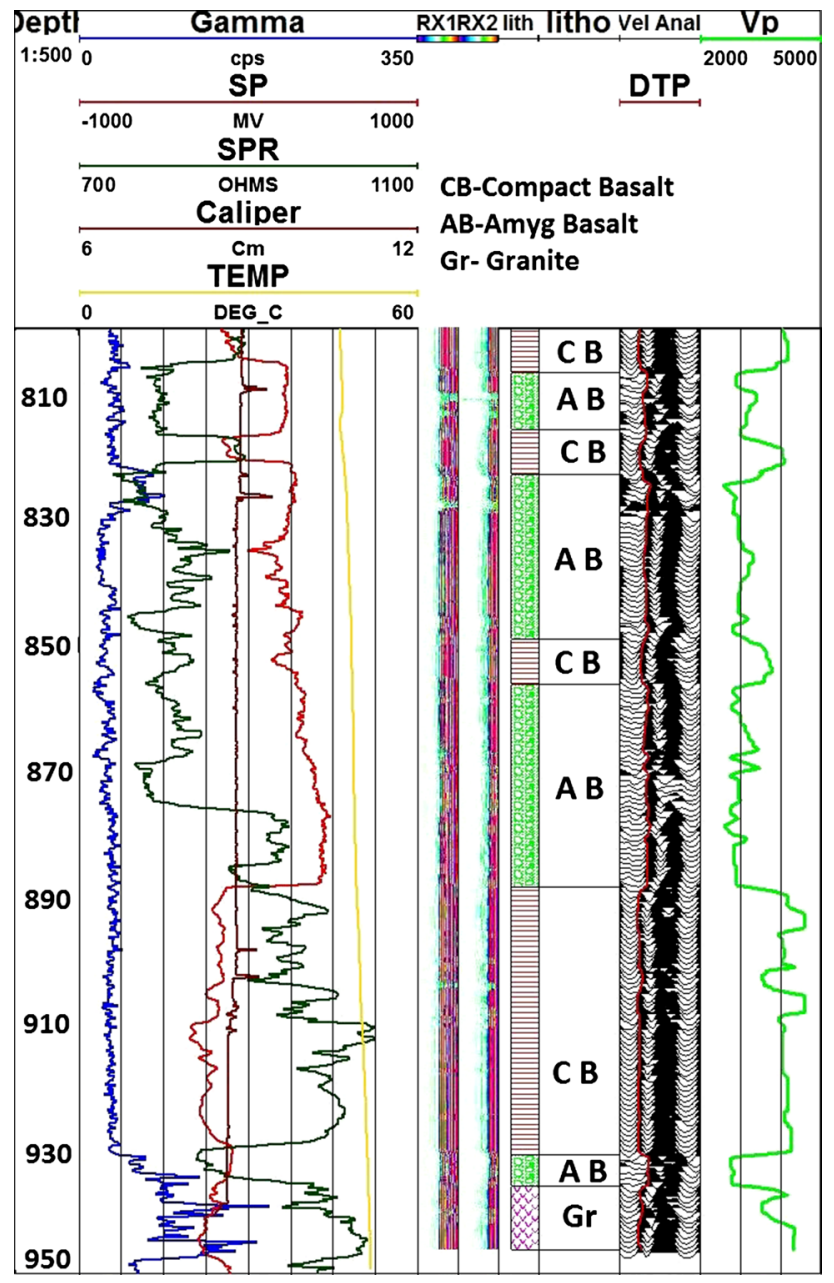

Fig. 6 Geophysical logs comprising gamma, SP, SPR, calliper, temperature and sonic, in the depth section $800-950 \mathrm{~m}$ in the borehole $\mathrm{KBH}-1$ at Rasati, near Koyna

basalt pile of $933 \mathrm{~m}$ at the site and sampled $589 \mathrm{~m}$ in the underlying granitic basement. Combining temperature gradient data with thermal conductivity measurements obtained so far on cores from the same borehole yields a tentative heat flow estimate of $45 \mathrm{~mW} \mathrm{~m}^{-2}$. This heat flow estimate is slightly higher relative to the previously reported value, but consistent with the overall low heat flow in the southern parts of the Deccan Traps province (Roy and Rao 1999, 2000). Preliminary temperature computations on the basis of heat flow, thermal conductivity and radiogenic heat production data indicate temperatures in the range $130-150^{\circ} \mathrm{C}$ at a depth of $6 \mathrm{~km}$ (Fig. 7).

Magnetotelluric studies

Previous magnetotelluric (MT) studies carried out in the Koyna region were reported by Sarma et al. (2004). Recently, a rolling array pattern of broad band MT network

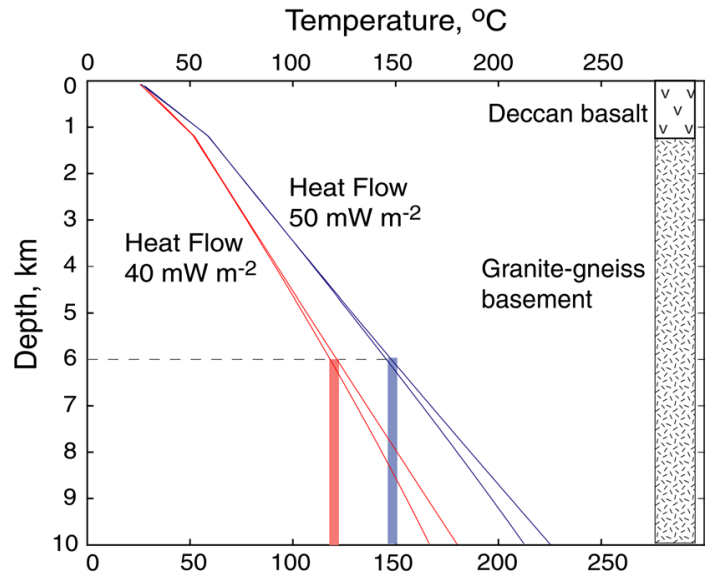

Fig. 7 Temperature-depth profiles in the upper crust in the Koyna area computed using a range of heat flow and heat production scenarios. Heat flow range is $40-50 \mathrm{~mW} \mathrm{~m}^{-2}$. A low heat production $\left(0.2 \mu \mathrm{W} \mathrm{m}^{-3}\right)$ for basalt and a range of heat production for granitegneiss $\left(0.5-1.5 \mu \mathrm{W} \mathrm{m}{ }^{-3}\right)$ has been considered. Estimated temperature at $6 \mathrm{~km}$ depth is in the range of $130-150{ }^{\circ} \mathrm{C}$

was deployed during 2012-2014 field campaigns to delineate the variations in subsurface resistivity structure of the region. One hundred MT stations were occupied. Two remote sites were operated to improve the signal-to-noise ratio by means of remote reference technique. A combination of processing methods has been adopted keeping in view the culturally affected noise in the data. Preliminary modelling studies, both $1 \mathrm{D}$ and 2D, have brought out the Deccan Trap thickness and the underlying basement configuration along selected profiles (shown in Fig. 3). A conspicuous conductive anomaly extending up to $1 \mathrm{~km}$ in depth beneath the Udgiri (KBH-2) borehole site has been modelled, which is consistent with the drilling observations. The study has brought out variations in the Deccan Trap from west to east as seen from the resistivity and phase depth sections (Fig. 8). Correlation with other data would be important to understand and delineate the probable fault zone(s).

Airborne gravity gradiometry and magnetic studies

In the early 1970s, regional-scale gravity measurements were taken over the entire Deccan Trap region that provided first-order information about the nature of the gravity field and a possible interpretation in terms of the subsurface structure (Kailasam et al. 1972). In the late 1990s, particularly after the Latur earthquake of 1993, gravity measurements with better accuracy and smaller station spacing were taken in parts of the Deccan Trap region (Tiwari et al. 2001). However, these gravity measurements were taken along the main roads, and thus, there were very few observations in the Koyna-Warna seismic zone due to 
Fig. 8 Resistivity-phase pseudo-EW depth sections along MT-1 profile passing through Koyna (top) and MT-2 profile passing through Udgiri (bottom). The locations of these profiles are shown in Fig. 3
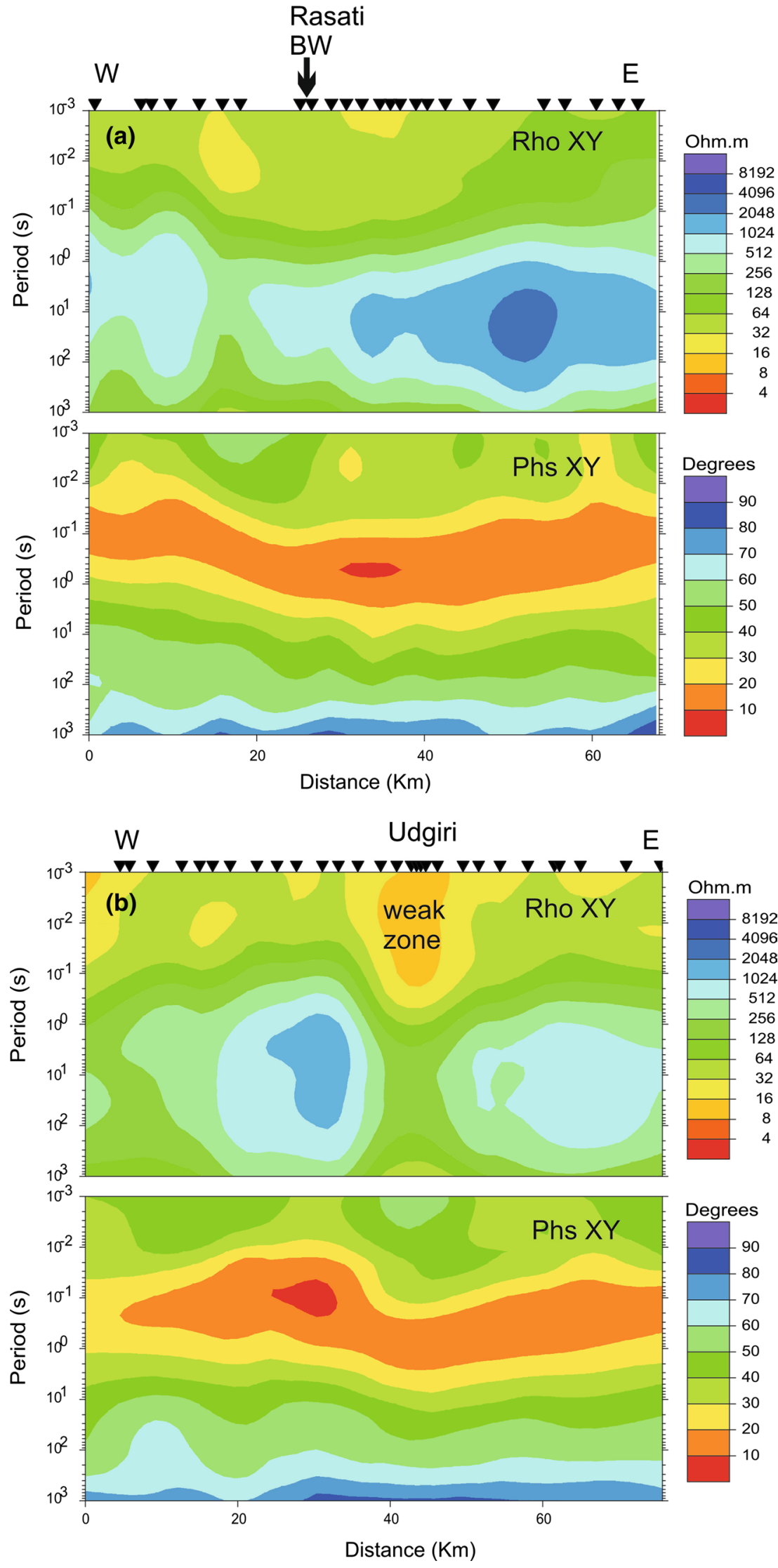
inaccessible terrain. These studies indicated a large wavelength gravity low encompassing Koyna-Warna earthquake region.

Considering inaccessibility and rough terrain, in the present study, low-elevation airborne gravity gradient and magnetic (AGGM) surveys were conducted to extend 2D model into 3D model for the entire Koyna region. Gravity gradient observations have advantages over conventional gravity data, which are less sensitive to the edges of bodies and contain no directional information. The primary objective of AGGM surveys is to infer 3D subsurface structure. AGGM data covering 5,012 line $\mathrm{km}$ were recorded along $\mathrm{N}-\mathrm{S}$ flight paths at an average $120-\mathrm{m}$ drape surface, cutting across the Koyna seismic zone. The initial model is based on earlier geophysical information such as deep seismic sounding (Kaila et al. 1981), deep resistivity sounding (Kailasam et al. 1976), palaeomagnetic studies (Jay et al. 2009), exploratory drilling (Roy et al. 2013a, b) as well as MT sounding carried out recently (Patro et al. pers. comm.). Figure 9 shows one of the cross sections from 3D model of the region. The location of the profile along with cross section, details of density, magnetic susceptibility and magnetization are also shown. Subsurface model provides thickness of the Deccan basalts, which varies from 400 to $1,700 \mathrm{~m}$ in the study region. Deccan basalts are thicker in the eastern side of the topographic escarpment compared with the western side. Our results also support the palaeomagnetic observations that normally magnetized basalts are above $~ 500-600 \mathrm{~m} \mathrm{msl}$.

\section{Airborne LiDAR studies}

Airborne LiDAR and orthophoto data are being acquired in the Koyna-Warna region in order to generate a highresolution and high-precision topographic model, which would be crucial to infer the surface geomorphology and active tectonics of the region. The topography in the area of LiDAR survey is $1,000 \mathrm{~m}$ on an average and the area is largely covered with vegetation.

LiDAR discrete return, waveform and intensity data as well as orthophoto images are being acquired in area of $1,064 \mathrm{~km}^{2}$ centred on the Koyna seismic zone. The aircraft uses a $125-\mathrm{kHz}$ laser at line intervals of $250 \mathrm{~m}$, hugging the terrain at about $600 \mathrm{~m}$ with flight speed of about $150 \mathrm{~km} \mathrm{~h}^{-1}$ to generate nominal point spacing (NPS) of $8-10 \mathrm{~m}^{-2}$. The processed data will reveal the details of the bare earth, leading to topographic details in terms of relief, steepness, relation with drainage patterns, which may provide information about structural conditions in the form of overhangs where unconsolidated materials have collapsed to form irregular ridges, moletracks, alluvials fans, doglegs across drainage, aligned vegetation or geothermal springs. Such features may expose conditions favourable to land uplift in a localized
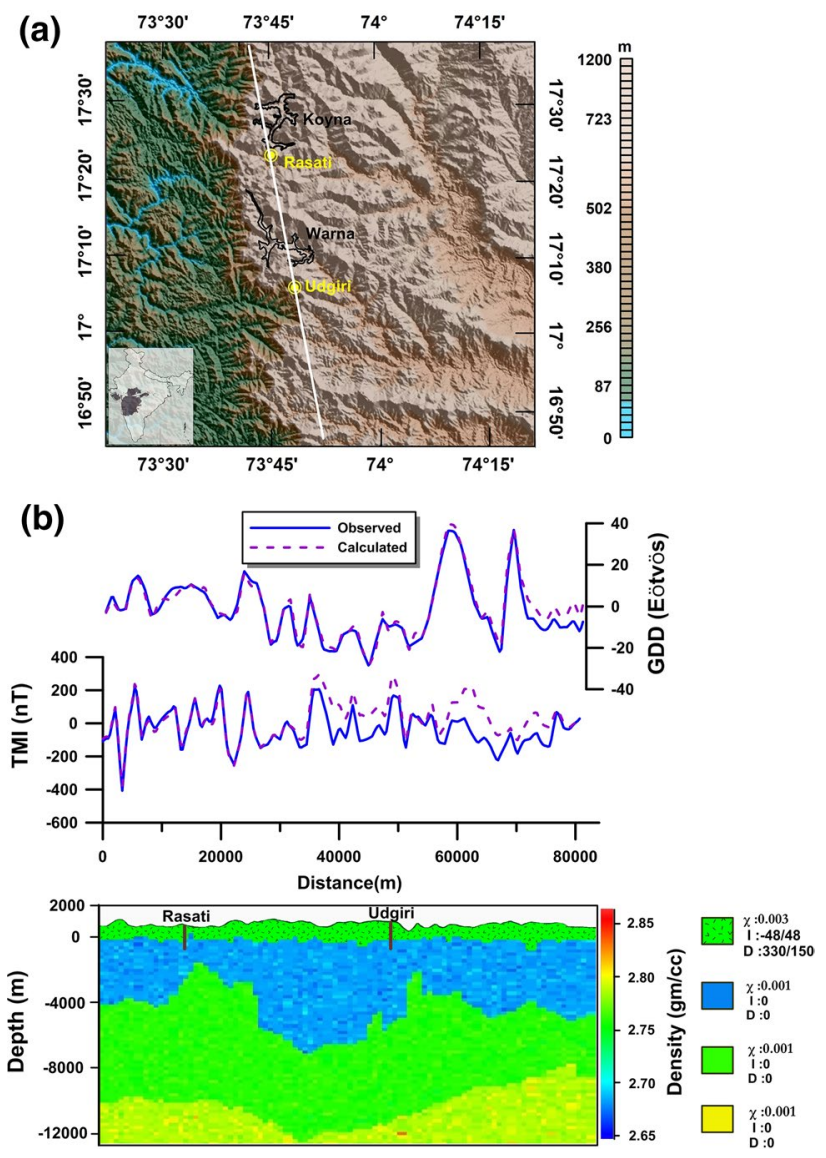

Fig. 9 a Topography map of the Koyna-Warna region along with the reservoirs and the two boreholes. White line shows location of a profile along which vertical cross section is generated from 3D subsurface model beneath Koyna-Warna region constructed from joint modelling of gravity, gravity gradients and magnetic data. b Vertical cross section along the profile. Observed and computed vertical gravity gradient (GDD) and magnetic anomalies are plotted for comparison

zone as well as response to hillslope erosion (Hunter et al. 2011). It is expected that mapping of the detailed surface geomorphology and inference of fine-scale structures and lineaments would in conjunction with the subsurface structure derived from drilling and other geophysical studies, help in understanding the stress field and seismo-tectonics of the region with respect to the reservoirs and their trigger effects on the seismicity in this region.

Borehole seismology

A borehole seismic network, the first of its kind, is being deployed to precisely locate earthquakes and refine the information about probable fault zones inferred on the basis of the existing network of surface seismic stations. The network would comprise eight sensors at depths of 1.2$1.5 \mathrm{~km}$ in the granitic basement, in boreholes surrounding the seismic cluster. By installing the sensors in the granitic 
Fig. 10 a Seismicity in the vicinity of the Warna reservoir during the study period from 2009 to April 2014. The two blocks A and B are each $2 \mathrm{~km} \times 2 \mathrm{~km}$ in area. b Focal depth sections in the two blocks $\mathrm{A}$ and $\mathrm{B}$ within the Warna seismic cluster shown in Fig. 10a

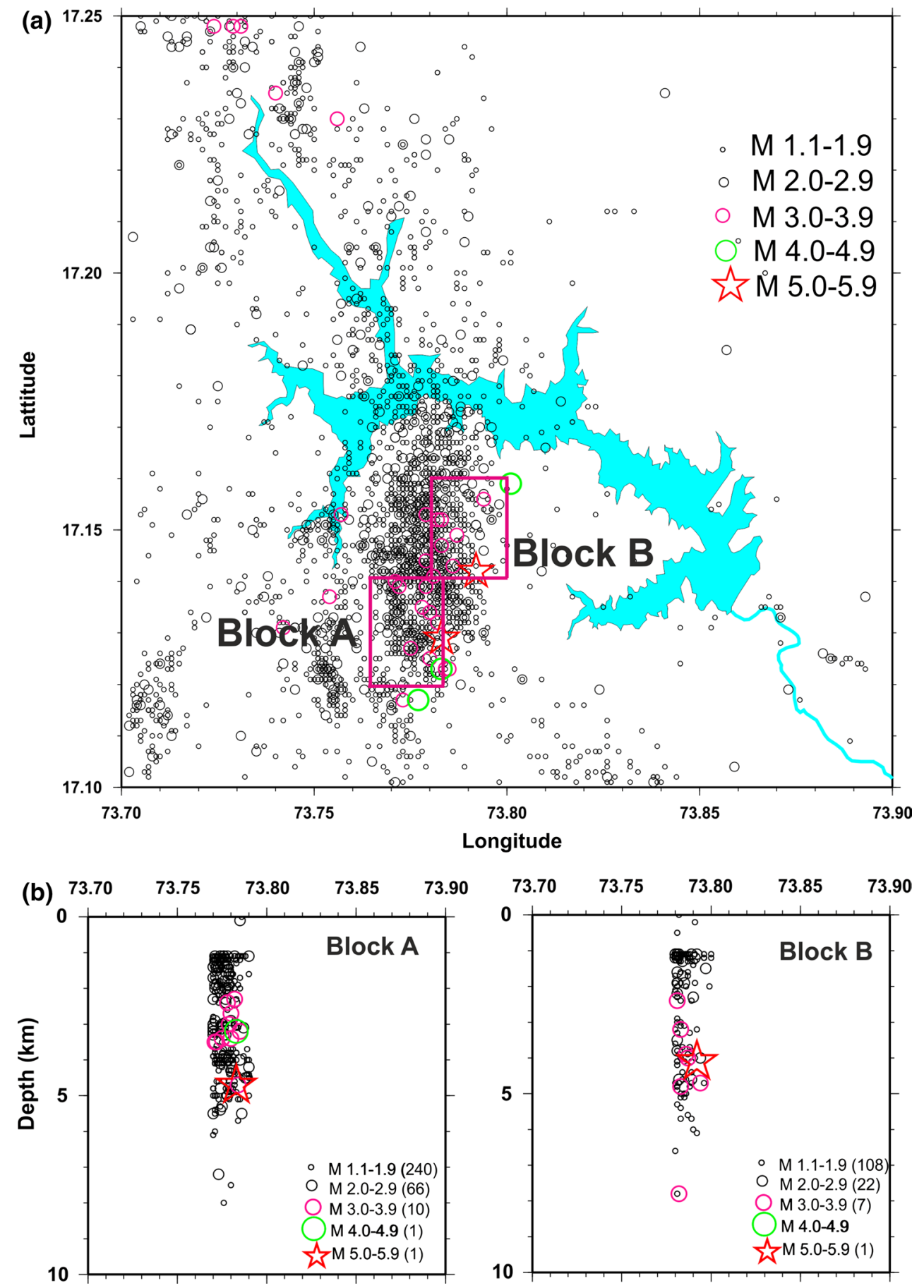

basement, the noise due to the overlying basalt cover is effectively eliminated, yielding clean records that allow identification of smaller earthquakes with better precision. The seismometers are of Sunfall make with $4.5-\mathrm{Hz}$ threecomponent sensors placed at the bottom of each borehole with the Reftek recording system on the surface connected through cables. Two borehole seismometers are already installed and are functional while six more are planned to be installed in the near future.

\section{Koyna seismicity and probable sites for scientific deep drilling}

Analysis of earthquake data sets from the Koyna-Warna area, carried out recently using improved techniques, has provided crucial information about the overall location of the target zone for deep drilling and also reasonable information about the potential fault alignments within the zone. The plot of seismicity in the area during August 2005 until December 
Fig. 11 a Seismicity in the Koyna region during 2009 to April 2014. The three blocks C, $\mathrm{D}$ and $\mathrm{E}$ are each $2 \mathrm{~km} \times 2 \mathrm{~km}$ in area. b Focal depth sections in the three blocks C, D and E shown in Fig. 11a

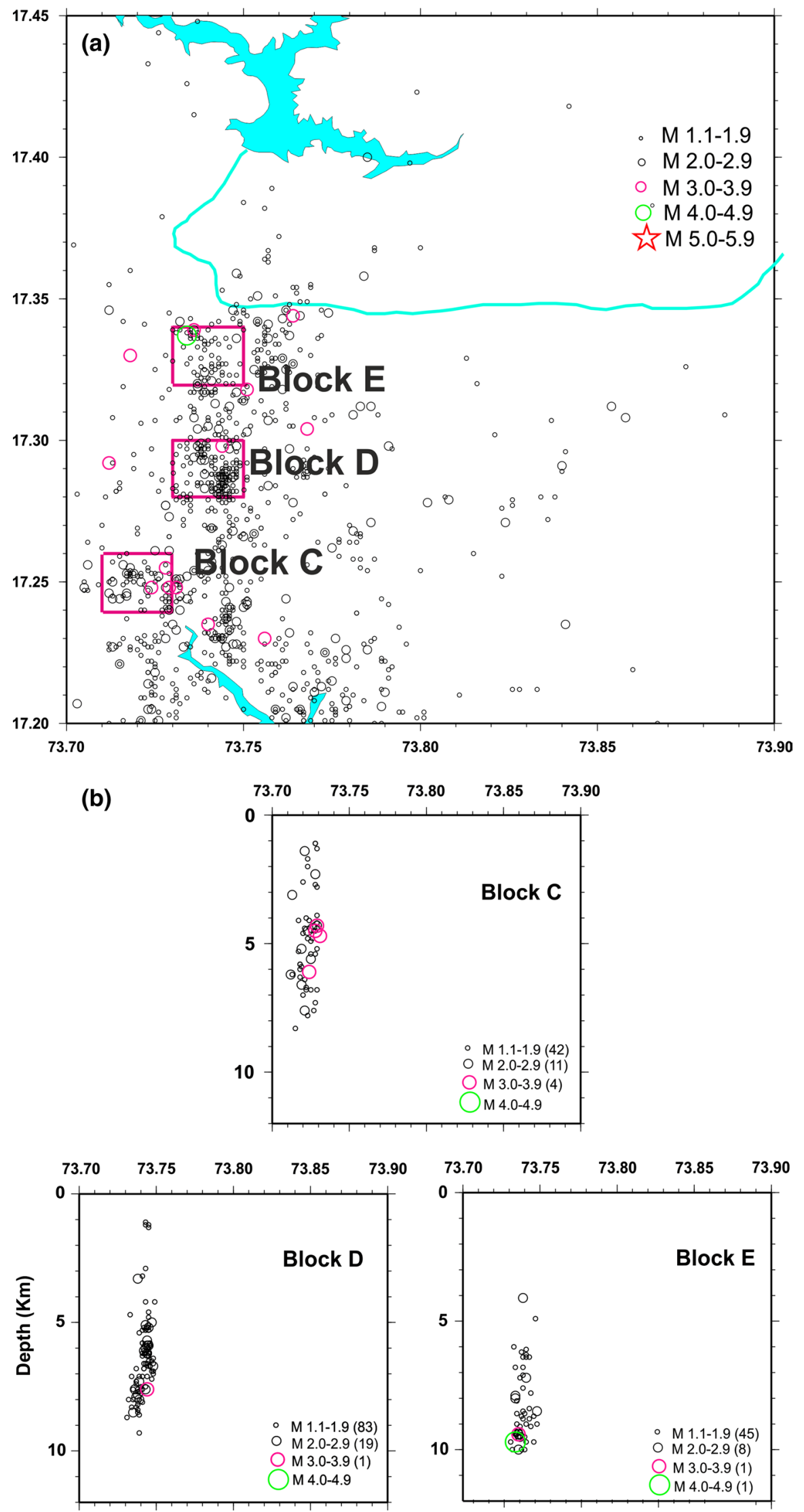


2013 (Fig. 1) clearly shows a significant seismic cluster to the south of Warna reservoir. Earthquakes of magnitude $M \geq 1.1$ during the period 2009-2014 in two $2 \mathrm{~km} \times 2 \mathrm{~km}$ blocks A and B near the Warna reservoir occur mostly in the depth range $1-5 \mathrm{~km}$ (Fig. 10a, b). This distribution provides for the most prospective location for the deep borehole drilling. In the Koyna region, the depth sections in three blocks C, D and $\mathrm{E}$ show a slightly deeper distribution of hypocenters between 5 and $9 \mathrm{~km}$ (Fig. 11a, b). This also is a potential site for deep borehole drilling. Both the sites are accessible for drilling and indicate the possibility of reaching the hypocentral region of the $M \geq 2$ earthquakes within a depth of about $5-7 \mathrm{~km}$.

\section{Plan of deep borehole}

Although several studies have clearly established the association of continued triggered earthquakes at Koyna with the precipitation driven loading and unloading of the Koyna and Warna reservoirs, the triggering mechanism is little understood. Existing geological, hydrological and geophysical studies in the region provide a good initial framework to study the regional tectonic setting, but lack critical inputs needed to explore the physical mechanisms that connect the reservoir water level changes to the occurrence of earthquakes. Our knowledge about the physical properties of rocks and fluids in the fault zones and how they affect the build-up of stress over extended periods of time is limited by the lack of data from the near-field region. To address this critical information gap, it is proposed to undertake scientific deep drilling at a carefully chosen site and set up an observatory at depth to study pre-seismic, co-seismic and post-seismic changes in physical, chemical and mechanical properties in the near field of earthquakes. By instrumenting the deep borehole for long-term monitoring of critical parameters such as seismicity, temperature, fluid/gas and pore pressure, it may be possible to obtain unprecedented new information on the temporal changes of those parameters associated with earthquake occurrences.

To set up the deep observatory, it is proposed to drill a 5,000-m-deep borehole within the seismic cluster to the south of Warna reservoir (Fig. 3). This site is appropriate because it has been active for the past decade, and it would be possible to reach the near field of repeating $M \geq 2$ earthquakes by drilling to about 5,000 $\mathrm{m}$ depth (Gupta et al. 2011a). More precise information on the hypocenter locations that would shed new light on the geometry of the fault zones and thus guide the trajectory of the deep borehole will be estimated from a network of 6-8 borehole seismometers in the granitic basement, surrounding the seismic zone. A vertical borehole is planned to a depth of about $5,000 \mathrm{~m}$, with three near-horizontal holes drilled between 4,000 and 5,000 $\mathrm{m}$ depth so as to reach the near field of the earthquakes in the cluster (Fig. 12). Alternatively, the borehole would be deviated towards the

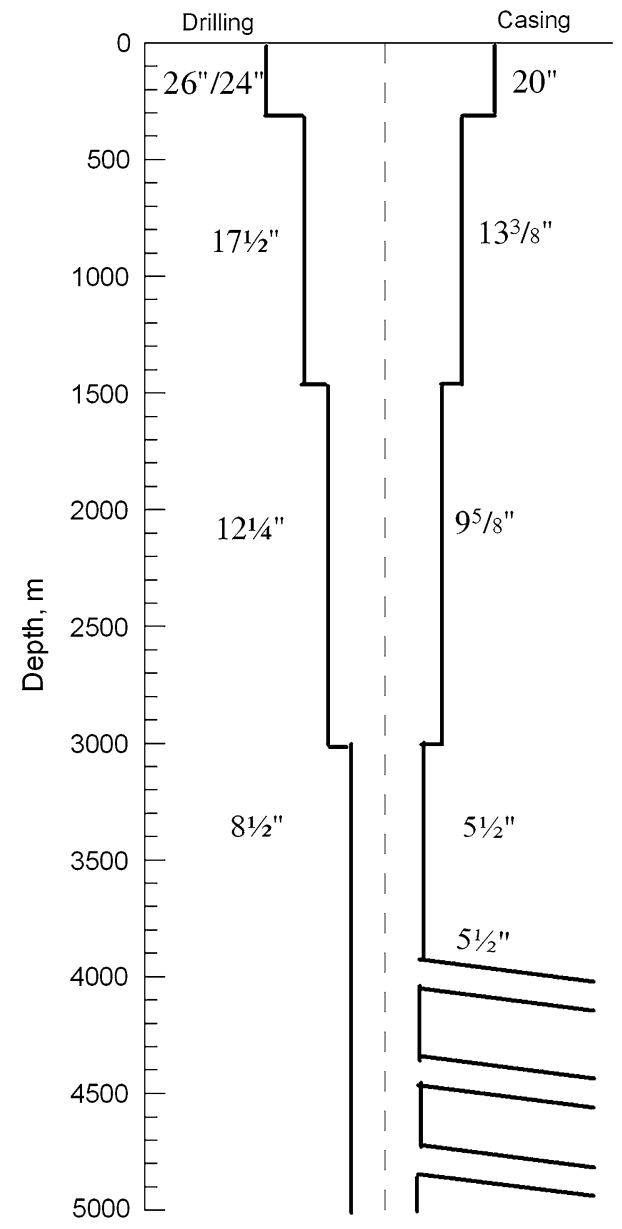

Fig. 12 Schematic configuration of the proposed deep borehole in Koyna-Warna area (see text for details). The laterals would be directed towards the hypocentral region of repeating $M \geq 2$ earthquakes within the seismic cluster located to the south of the Warna reservoir

hypocentral region after reaching a vertical depth of 3,000 m. The borehole will be cased and cemented for carrying out measurements and monitoring for several years.

The deep borehole observatory will comprise a suite of instruments and sensors installed inside the borehole. Potential installations include (1) arrays of three-component seismometers and deformation sensors at different levels, (2) pore pressure transducers, (3) temperature sensors and (4) in-line gas/fluid testing equipment. Monitoring of several parameters will be continued for a number of years after completion of drilling and instrumentation. Analysis of these data sets and modelling studies would lead to comprehending the genesis of reservoir-triggered earthquakes.

The proposed drilling project addresses a key ICDP scientific theme "active faulting and earthquakes". The project will generate new information and knowledge about artificial water reservoir-triggered seismicity within an intraplate setting but also complement the other active 
fault zone drilling projects including the SAFOD (USA), Nojima fault (Japan), NanTroSEIZE (Japan), Chelungpu fault (Taiwan), Gulf of Corinth (Greece) and the GONAF (Turkey) (Zoback et al. 2011; Ma et al. 2006; Ando 2001; Cornet et al. 2004; Bulut et al. 2014).

\section{Summary}

The persistent seismicity at Koyna during the past five decades makes it a natural laboratory to study the genesis of earthquakes in a stable continental region and to elucidate the role of artificial water reservoirs in triggering earthquake activity by setting up a deep borehole observatory. Prior to undertaking scientific deep drilling and experimentation, an exploratory phase of geophysical investigations and drilling is being carried out in the Koyna area. These studies have brought forth critical new information that would guide the design of the deep borehole observatory. It is now clear that the proposed deep borehole will go through about $1-\mathrm{km}$ thick Deccan Traps, which is directly underlain by granite-gneiss basement. The basement granitoids are highly fractured and crushed at multiple depths with evidences for shear movement, possibly as a consequence of intense seismic activity in the area. The upper few kilometres of the crust is characterized by moderate temperature regime, with temperatures unlikely to exceed $150{ }^{\circ} \mathrm{C}$ at a depth of $6 \mathrm{~km}$. Analysis of broadband seismic data indicate the possibility of reaching the hypocentral region of the $M \geq 2$ earthquakes within a depth of about 5-7 km. Based on the scientific work carried out so far, a tentative location for setting up of the deep borehole observatory has been identified. A first-order plan of scientific deep drilling and observational facilities to be developed has been also presented.

Acknowledgments We are grateful to the Government of Maharashtra for facilitating the drilling, airborne and other investigations, to the Atomic Minerals Directorate (AMD), Hyderabad, for providing technical advice at various stages of drilling operations and geological core logging, to Mineral Exploration Corporation Ltd. (MECL), Nagpur, for providing geophysical logging and geological core logging services. Discussions with ICDP-OSG and ONGC Ltd. regarding scientific deep drilling were helpful. The study was funded by the Ministry of Earth Sciences, Government of India.

\section{References}

Ando M (2001) Geological and geophysical studies of the Nojima Fault from drilling: An outline of the Nojima Fault Zone Probe. The Island Arc 10: 206-214

Bell ML, Nur A (1978) Strength changes due to reservoir induced pore pressure and stresses and application to Lake Oro-Berrocal. J Geophys Res 83:4469-4483

Bulut F, Bohnhoff M, Dresen G, Raub C, Kilic T, Kartal RF, Kadirioglu FT, Nurlu M, Ito H, Malin P (2014) GONAF-a deep geophysical observatory at the North Anatolian fault: permanent downhole monitoring of a pending major earthquake. Geophys. Res. Abstracts, EGU general assembly 2014, vol 16, EGU2014-15398-1

Cornet FH, Doan JML, Moretti I, Borm G (2004) Drilling through the active Aigion Fault: the AIG10 well observatory. CR Geosci 336:395-406

Do Nascimento AF, Cowie PA, Lunn RJ, Pearce RG (2004) Spatiotemporal evolution of induced seismicity at Acu reservoir, NE Brazil. Geophys J Int 158:1041-1052

Gough DI, Gough WI (1970a) Stress and deflection in the lithosphere near Lake Kariba, 1. Geophys J Int 21:65-78

Gough DI, Gough WI (1970b) Load induced earthquakes at Kariba, 2. Geophys J Int 21:79-101

Gupta HK (1992) Reservoir-induced earthquakes. Elsevier, Amsterdam

Gupta H (2002) A review of artificial reservoir triggered earthquakes with special emphasis on earthquakes in Koyna, India. Earth Sci Rev 58:279-310

Gupta H (2011) Artificial water reservoir triggered earthquakes. In: Gupta H (ed) Encyclopedia of solid earth geophysics. Springer, Berlin, pp 15-24

Gupta ML, Gaur VK (1984) Surface heat flow and probable evolution of Deccan volcanism. Tectonophysics 105:309-318

Gupta HK, Rastogi BK (1976) Dams and earthquakes. Elsevier, Amsterdam

Gupta HK, Rastogi BK, Narain H (1972a) Common features of the Reservoir associated seismic activities. Bull Seismol Soc Am 62:481-492

Gupta HK, Rastogi BK, Narain H (1972b) Some discriminatory characteristics of earthquakes near the Kariba, Kremasta and Koyna artificial lakes. Bull Seismol Soc Am 62:493-507

Gupta HK, Rao CVRK, Rastogi BK, Bhatia SC (1980) An investigation of earthquakes in Koyna region, Maharashtra, for the period 1973 through December 1976. Bull Seismol Soc Am 70(5): 1833-1847

Gupta HK, Shashidhar D, Metilda P, Mandal P, Dimri VP (2006) Prediction of an $\mathrm{M} \sim 4$ earthquake in the Koyna region comes true! J Geol Soc India 68:149-150

Gupta HK, Shashidhar D, Metilda P, Mandal P, Rao NP, Kousalya M, Satyanarayana HVS, Dimri VP (2007) Earthquake forecast appears feasible at Koyna, India. Curr Sci 93(6):843-848

Gupta HK, Shashidhar D, Mallika K, Rao NP, Srinagesh D, Satyanarayana HVS, Saha S, Naik RTB (2011a) Short term earthquake forecasts at Koyna, India. J Geol Soc Ind 77:5-11

Gupta HK, Nayak S, The Koyna Workshop Committee (2011b) Deep scientific drilling to study reservoir-triggered Earthquakes in Koyna, Western India. Sci Drill. doi:10.2204/iodp.sd.12.07.2011

Hunter et al (2011) LiDAR assisted in identification of an active fault near Truckee, California. Bull Seismol Soc Am 101(3):1162-1181

Jay AE, Mac Niocaill C, Widdowson M, Self S, Turner W (2009) New palaeomagnetic data from the Mahabaleshwar Plateau, Deccan Flood Basalt Province, India: implications for the volcanostratigraphic architecture of continental. J Geol Soc Ind 166:13-24

Kaila KL, Reddy PR, Dixit MM, Lazrenko MA (1981) Deep crustal structure at Koyna, Maharashtra indicated by deep seismic soundings. J Geol Soc India 22:1-16

Kailasam LN, Murty BGK, Chayanulu AYSR (1972) Regional gravity studies of the Deccan Trap areas of Peninsular India. Curr Sci 41:403-407

Kailasam LN, Reddy AGB, Rao J, Sathyamurthy K, Murthy BSR (1976) Deep electrical resistivity soundings in Deccan Trap region. Curr Sci 45:4-16

Kaiser J (1953) Arch. Eisenhuttenwesen 24:43-45 (in German)

Ma K-F et al (2006) Slip zone and energetics of a large earthquake from the Taiwan Chelungpu-fault drilling project. Nature 444:473-476. doi:10.1038/nature05253 
Rao NP, Roy S, Arora K (2013) Deep Scientific drilling in Koyna, India - Brainstorming workshop on geological investigations 19-20 March 2013. J Geol Soc India 81:722-723

Roeloffs EA (1988) Fault stability changes induced beneath a reservoir with cyclic variations in water level. J Geophys Res 93:2107-2124

Roy S, Rao RUM (1999) Geothermal investigations in the Latur earthquake area, Deccan Volcanic Province, India. Tectonophysics 306:237-252

Roy S, Rao RUM (2000) Heat flow in the Indian shield. J Geophys Res Solid Earth 105:25587-25604

Roy S, Rao NP, Akkiraju VV, Goswami D, Sen M, Gupta HK, Bansal BK, Nayak S (2013a) Granitic basement below Deccan traps unearthed by drilling in the Koyna Seismic zone, Western India. J Geol Soc Ind 81:289-290

Roy S, Akkiraju VV, Goswami D, Vyas D, Ravi G, Purnachandra Rao N, Sen M, Gupta H (2013b) First results from borehole investigations at Koyna, India, site of proposed scientific deep drilling to study reservoir triggered seismicity. In: Proceedings of American Geophysical Union Fall Meeting, 9-13 December 2013, San Francisco

Sarma SVS, Patro BPK, Harinarayana T, Veeraswamy K, Sastry RS, Sarma MVC (2004) A magnetotelluric (MT) study across the Koyna seismic zone, western India: evidence for block structure. Phys Earth Planet Inter 142:23-36
Shashidhar D, Rao NP, Gupta HK (2011) Waveform inversion of local earthquakes using broad band data of Koyna-Warna region, western India. Geophys J Int 185:292-304

Shashidhar D, Rao NP, Srinagesh D, Gupta HK, Satyanarayana HVS, Suresh G, Satish A (2013) The 14 April 2012 Koyna Earthquake of Mw 4.8: insights into active tectonics of the Koyna region. J Seismol 17(4):1345-1353

Snow DT (1972) Geodynamics of seismic reservoirs. In: Proceedings of the symposium on percolation through fissured rocks, Deutsche Gessellschaft fiir Erd- und Grundbau, Stuttgart, Germany, T2-J, pp 1-19

Talwani P (1997a) Seismotectonics of the Koyna-Warna area, India. Pure Appl Geophys 150:511-550

Talwani P (1997b) On the nature of reservoir-induced seismicity. Pure Appl Geophys 150:473-492

Talwani P, Cobb JS, Schaeffer MF (1999) In-situ measurements of hydraulic properties of a shear zone in northwestern South Carolina. J Geophys Res 104:14993-15003

Tiwari VM, Vyaghreswara Rao MBS, Mishra DC (2001) Density inhomogeneities under Deccan Volcanic Province as derived from gravity data. J Geodyn 31:1-17

Zoback MD, Hickman S, Ellsworth WL (2011) Scientific drilling into the San Andreas fault zone-an overview of SAFOD's first five years. Sci Drill. doi:10.2204/iodp.sd.11.02.2011 